\title{
Popular and unpopular infectious agents linked to primary biliary cirrhosis
}

\author{
Andreas L. Koutsoumpas • Stephen Kriese • \\ Eirini I. Rigopoulou
}

Received: 24 September 2012/ Accepted: 3 October 2012/Published online: 23 October 2012

(C) Springer-Verlag Italia 2012

\begin{abstract}
Primary biliary cirrhosis (PBC) is a progressive cholestatic liver disease characterized by the autoimmune destruction of the biliary epithelial cells of the small and medium-size bile ducts. The disease affects middle aged women and usually affects more than one member within a family. The pathognomonic serological hallmark of the disease is the presence of circulating anti-mitochondrial antibodies, and disease-specific anti-nuclear antibodies. Susceptibility genes and environmental risk factors such as infections and smoking have been reported as important for the development of the disease. Among the environmental agents, infectious triggers are the best studied. Most of the work published so far has investigated the role of infections caused by Novosphingobium aromaticivorans and Escherichia coli. This review will discuss the popular and unpopular infectious agents causatively linked to PBC. It will also examine reports investigating the epidemiological aspects of the disease and their direct or indirect implications to bacterial-induced PBC.
\end{abstract}

Keywords Autoimmunity - Autoimmune disease · Bile ducts · Cholestasis · Cross-reactivity · Liver . Immunity $\cdot$ Tolerance $\cdot$ Mimicry

\footnotetext{
A. L. Koutsoumpas

Sismanoglion General Hospital, Athens, Greece

S. Kriese

Liver Unit, King's College Hospital, London, UK

E. I. Rigopoulou ( $₫)$

Department of Medicine, University of Thessaly Medical

School, Viopolis, Mezourlo, 41110 Larissa, Greece

e-mail: eirigopoulou@med.uth.gr
}

\author{
Abbreviations \\ AMA Anti-mitochondrial antibody \\ ANA Anti-nuclear antibody \\ BEC Biliary epithelial cell \\ NKT Natural killer T cells \\ OADC Oxo-acid dehydrogenase complex \\ OGDC 2-Oxoglutarate dehydrogenase complex \\ PBC Primary biliary cirrhosis \\ PDC Pyruvate dehydrogenase complex \\ UTI Urinary tract infection
}

\section{Introduction}

Primary biliary cirrhosis (PBC) is an autoimmune cholestatic disease, which is characterized by bile duct loss leading to fibrosis, cirrhosis and subsequent liver failure [15]. The disease shows a remarkable female predominance, mainly affecting middle aged women and at times affects several members within a family [6-11]. The disease can run an asymptomatic course. The complaints of symptomatic patients include non-specific symptoms such as fatigue, pruritus, sicca symptomatology and arthralgias [1-5, 12]. Patients at more advanced stage of the disease suffer from symptoms of liver decompensation and portal hypertension $[1-5,12]$. The disease progresses at slow pace, but the progress rates are difficult to predict [1-5, 12-14].

The widely accepted diagnostic criteria for PBC are based on biochemically-evident cholestasis, disease-specific autoantibody serology and histological features consistent with PBC $[1-5,12,13,15,16]$. Cholestatic markers assisting the diagnosis include increased levels of alkaline phosphatase and $\gamma$ GT [1-5]. More than $90 \%$ of the patients have detectable anti-mitochondrial antibodies 
(AMA), while PBC-specific anti-nuclear antibodies (ANA) are present in up to $50 \%$ of the affected cases [15-23]. The mere presence of AMA predicts the development of PBC in asymptomatic patients, as a significant proportion of acholestatic women with positive AMA tests develop clinical features of PBC over time [6, 14-17, 24-26].

PBC-specific AMA targets the 2-oxo-acid dehydrogenase complexes, and in particular the E2 subunit of the pyruvate dehydrogenase complex (PDC) in approximately 80-90 \% of AMA-positive cases [20, 27-38]. The E2 subunits of branched-chain 2-oxo-acid dehydrogenase complex (BCOADC) and 2-oxo-glutarate dehydrogenase complex (OGDC) are targeted to a lesser extent, while reactivity to the $\mathrm{E} 1 \alpha$ and $\mathrm{E} 1 \beta$ subunits of $\mathrm{PDC}$ has been considered less significant [20, 27-36]. Most of the authors agree that neither the titre nor the presence of AMA bears clinical significance [15-17, 39-41]. The detection of AMA is usually performed by indirect immunoflourescence assay (IFA). Immunoblotting was more popular in the past, but in recent years has been replaced by ELISA or line/dot blot immunoassays [15-17, 40-51]. ANA specifically found in PBC recognise the nuclear body proteins such as sp100, promyelocytic leukaemia, sp140, and small ubiquitin-like modifiers, or nuclear envelope antigens such as gp210 and nucleoporin p62 [15, 16, 19, 52-56]. Reactivity to nuclear body proteins gives a multiple nuclear dot pattern and antinuclear membrane antibodies give a nuclear rim pattern by IFA [15, 16, 18, 57, 58]. When AMA are absent, ANA specific for the disease appear to be more frequent. These ANA appear to have prognostic and clinical significance, and can be found in asymptomatic women and members of their family [18, 48, 52, 53, 57, 59-68].

The aetiopathogenesis of PBC remains poorly understood, and the mechanisms responsible for the development of AMA and ANA are theoretical [21, 69-72]. Whether PBC-specific autoantibodies are pathogenic is not known $[17,55,73,74]$. While some believe that these autoantibodies are just epiphenomena, others consider them as the indicators of autoantigen-specific processes involving CD4 and CD8+ T lymphocyte autoreactive populations which are able to inflict tissue damage $[17,55,71,73-76]$. The possibility that the mechanisms responsible for the induction of PBC-specific autoantibodies are also responsible for the pathogenesis of PBC has not been excluded [77, 78].

Most agree that infections by themselves are not sufficient to induce disease and that the other environmental agents such as toxins, as well as genetic factors are also important [28, 52, 65, 66, 73, 79-104]. The striking female predominance of PBC has also been the focus of increased interest in the recent years [78, 94, 105-108]. E. coli has been amongst the first infectious agents to be considered a likely trigger of the disease [28, 65, 70, 77, 82, 89-91, 109, 110]. Early epidemiological studies have shown that patients with PBC suffer more frequently than other patients with liver disease from recurrent urinary tract infections (UTI), which are more prevalent in PBC patients than in patients with other liver diseases [88, 90, 111]. More recent studies have replicated these findings [112, 113]. Within the last decade or so, Novosphingobium aromaticivorans has been considered a serious candidate and has been pathogenetically linked to the disease. Most work to support this view has come from one group that has provided serological and other experimental data to support the role of this agent with the development of the disease [52, 79, 82, 98, 99]. Other infectious triggers have also been studied, but the number of publications per agent is considerably outsized by that related to Novosphingobium aromaticivorans and E.coli [114]. Nevertheless, compared to other autoimmune liver diseases such as autoimmune hepatitis, the list of potentially harmful infectious agents linked to PBC is noteworthy [86, 95, 114]. Most of the infectious agents included in this list have led to studies failing to provide positive associations with $\mathrm{PBC}$, and the involved triggers have not been studied extensively due to the profound lack of scientific interest from competing groups.

The role of molecular mimicry

The mechanism of molecular mimicry has been widely used as an explanation for infectious-triggered autoimmunity (mainly viral hepatitides $\mathrm{B}$ and $\mathrm{C}$ ), and for the induction of autoimmune liver diseases due to infections (both viral and non-viral) $[17,52,65,66,70,73,74,79-82$, 84, 87, 98, 99, 110, 115]. As most epitopic regions of the AMA and ANA targets are known, the mechanism of molecular mimicry has been used as a tool to identify bacterial triggers of $\mathrm{PBC}$ that serve as targets of crossreactive responses $[70,110]$. This mechanism implies that because of the amino acid similarity between infectious and self epitopes, responses against the infectious agent will provoke the development of a cross-reactive response against mitochondrial and nuclear autoantigens (Table 1) [21, 69, 74]. These cross-reactive responses operate at the B- and T cell level [70, 116].

\section{Popular infectious triggers of PBC}

\section{N. aromaticivorans}

Experimental data have provided evidence that this aerobic, gram-negative bacterium may be involved in the development of PBC. Molecular mimicry involving $N$. aromaticivorans and mitochondrial autoantigens has been demonstrated [98, 117, 118]. Selmi et al. [98] were the 
Table 1 Molecular mimicry studies involving various infectious agents as the likely triggers of primary biliary cirrhosis. [52, 66, 79, 84, 85, $143,145,149]$

\begin{tabular}{lll}
\hline Infectious agent & In support of molecular mimicry & Against molecular mimicry \\
\hline E. coli & $\begin{array}{c}\text { Yes (both at B- and CD4 T cell } \\
\text { level) }\end{array}$ & $\begin{array}{c}\text { No (Antibody reactivity to E. coli) } \\
\text { PDC-E2 mimic is very weak }\end{array}$ \\
N. amoraticivorans & Yes (B cell) & \\
Lactobacilli & Yes (B cell) & \\
Mycobacteria & Yes (B cell level but & No (Lack of cross-reactivity for \\
& only & other typical or atypical \\
for M. gordonae) & mycobacteria) \\
Helicobacter pylori & & No (B- or CD4 T cell) \\
Psuedomonas aeruginosa & Yes (CD4 T cell) & No (B cell) \\
Human cytomegalovirus & & No (B cell) \\
Haemophilus influenzae & & \\
Neurospora crassa & Yes (CD4 T cell) & \\
Neisseria meningitis & Yes (CD4 T cell) & \\
Acholeplasma laidlawii & Yes (CD4 T cell) & \\
Azotobacter vinelandii & Yes (CD4 T cell) & No (CD4 T cell) \\
Pseudomonas putida & Yes (CD4 T cell) & No (CD4 T cell) \\
Human Ecotropic virus & & No (CD4 T cell) \\
Streptomyces aureofaciens & & No (CD4 T cell) \\
Bacillus thuringiensis, Bacillus & & \\
subtilis & &
\end{tabular}

first to identify two $N$. aromaticivorans proteins with striking amino acid homology with PDC-E2. All PBC patients who recognised PDC-E2 reacted with the bacterial proteins, and molecular testing has led to the isolation of $N$. aromaticivorans in faecal samples from PBC patients. A subsequent study has shown that $N$. aromaticivorans contains PDC-E2like proteins in their cell membranes [119]. Reactivity to $N$. aromaticivorans prevailed over the reactivity to that against the mimicking $E$. coli antigen. Another study from Iceland reported that patients with $\mathrm{PBC}$ and their first degree relatives had antibodies against $N$. aromaticivorans [120]. These anti-microbial antibodies had the ability to cross-react with mitochondrial autoantigens. Individuals with antibodies to $N$. aromaticivorans, but without evidence of PBC, could develop the disease some years later [120]. Although $25 \%$ of both PBC and FDR groups had $N$. aromaticivorans in faecal samples, only those with $\mathrm{PBC}$ had antibodies against them [120].

Animal studies with mice inoculated with $N$. aromaticivorans provided data to support the presence of $\mathrm{IgG}$ and IgA antibodies against bacterial and mammalian PDC-E2 [118]. Also, the inoculated mice developed histological features of $\mathrm{PBC}$ in a Natural Killer $\mathrm{T}$ cell dependent manner [118]. Of great interest is the fact that in this experimental setting, transfer experiments of $\mathrm{T}$ cells from infected to uninfected mice led to the transfer of bile duct pathological alterations, that were preventable by the early administration of antibiotic treatment [118].
E. coli

When Burroughs and Baum [87] formed the hypothesis that molecular mimicry between human and E. coli PDCE2 is responsible for the induction of AMA and autoreactive lymphocytes reacting with PDC-E2, they did not know what was going to follow. Several studies have been conducted based on the assumption that $E$. coli infection may trigger PBC (Table 2). Several reports have shown that sera from PBC patients cross-react with bacterial and human PDC-E2 [20, 89-91, 121, 122]. Subsequent immunological findings have been obtained to demonstrate the presence of cross-reactive antibodies targeting human PDC-E2 and E. coli mimics from proteins unrelated to PDC-E2 or other members of the 2-OADC [66, 84]. While protein-protein BLAST search has identified several E-coli sequences sharing homology with human PDC-E2, very few of those were cross-recognised by PBC sera [66, 82, 99, 110].

Reactivity to human PDC-E2 is much stronger compared to that against mammalian PDC-E2 [123], and this also appears to be the case for OGDC-E2 [124]. At the peptide level, antibodies against PDC-E2 $212-226$, which is the core epitopic region of human PDC-E2, do not appear to cross-react with $E$. coli $\mathrm{PDC}-\mathrm{E} 2$ sequence [52], and this may be due to the lack of significant structural/antigenic mimicry [82]. The core region recognised by the anti-PDCE2 antibodies significantly overlaps with the CD4 and CD8 
Table 2 Major findings of the studies investigating the role of E. coli infection in the pathogenesis of primary biliary cirrhosis (PBC)

\begin{tabular}{|c|c|c|}
\hline & & Reference \\
\hline Clinical & $\begin{array}{l}\text { Women with PBC have more frequently recurrent urinary tract infections (UTI) compared to women with } \\
\text { other liver diseases }\end{array}$ & [88-91] \\
\hline \multirow[t]{2}{*}{ Epidemiological } & Large-scale epidemiological studies have shown that UTI is an independent risk factor associated with PBC & $\begin{array}{l}{[112,113,} \\
127]\end{array}$ \\
\hline & A history of UTI precedes the development of PBC for several years & [129] \\
\hline \multirow[t]{2}{*}{ Immunological } & $\begin{array}{l}\text { Women with recurrent UTI have, but without evidence of liver involvement, have detectable AMA and PBC- } \\
\text { specific ANA }\end{array}$ & {$[80,89]$} \\
\hline & E. coli mimics and human PDC-E2 are cross-recognised by antibodies and $\mathrm{T}$ cells of patients with PBC & {$[66,84,85]$} \\
\hline Animal studies & $\begin{array}{l}\text { Recurrent } E \text {. coli infection can induce in animals the production of AMA and histological features compatible } \\
\text { with PBC }\end{array}$ & [156] \\
\hline
\end{tabular}

$A M A$ anti-mitochondrial antibodies, $A N A$ anti-nuclear antibodies

T cell epitope on PDC-E2. E.coli and human PDC-E2 cross-react at the CD4 and CD8 T cell levels [84, 85, 125, 126]. Shimoda et al. [84, 85] have shown that the ExDK motif is essential for $\mathrm{T}$ cell epitope recognition. It has also been shown that $\mathrm{T}$ cell lines specific to the human PDC-E2 autoepitope developed from peripheral blood mononuclear cells or liver infiltrating cells obtained from patients with PBC can also be activated by a motif sharing OGDC-E2 peptide of $E$. coli $[84,85]$. A relationship between evidence of recurrent UTI and the presence of PBC-specific responses against sp100 has been noted [80].

Several studies have reported an increased incidence of recurrent UTI in female PBC patients [88, 112, 127], and E. coli is isolated in most cases [88]. Others failed to find an epidemiological association between $E$. coli infection and PBC [128]. A recent epidemiological study has suggested a causal relationship between UTIs specific for the disease and PBC. This association preceded the diagnosis of PBC by at least 5 years [129]. Such a relationship has not been noted in the past, and re-enforces the link between E. coli and PBC.

\section{Lactobacillus delbrueckii}

L. delbrueckii subsp. bulgaricus is a gram positive rod used in the production of yoghurt, but is also found in the gastrointestinal tract and the vagina in humans. Vaginal lactobacilli maintain a flora which is protective against urinary tract infections. Alterations in the normal bacterial flora may result in bacterial vaginitis and increased UTI incidence. It appears that $L$. delbrueckii subsp. bulgaricus shares a striking amino acid homology with the core epitopic region on PDC-E2, and the mimicry shared by the infectious and human sequences is unique [52]. Crossreactive antibody responses against the mimicking sequences belong to the IgG3 subclass and are specifically present in patients with PBC. Reactivity to the lactobacillus mimic can be found in healthy and pathological controls, but belongs exclusively to IgG4 subclass. A case of a German woman, who went on to develop PBC after vaccination with lactobacillus for recurrent vaginitis, has added support to the notion that this infectious agent may cause the disease [79]. The serum of this woman contained antibodies against the lactobacillus mimic, and crossrecognised the human PDC-E2 homologous sequence [79]. In a hypothetical scenario, changes of the normal vaginal flora provide the impetus for microbial infections that contribute to the development of $\mathrm{PBC}$ via molecular mimicry or other mechanisms. No other studies have investigated the role of lactobacilli in PBC.

\section{Betaretroviruses}

The extent by which betaretroviruses are involved in the development of PBC is currently unknown [130, 131]. Mason's group has studied this topic in great detail. The initial finding of antibody reactivity to retroviruses has been complemented by the demonstration of viral particles in BECs using electron microscopy [96, 101, 132]. Later on, the same group has reported the cloning of a human betaretrovirus (HBRV) sequence with a remarkable nucleotide homology to the mouse mammary tumour virus (MMTV) through a screening of a PBC biliary epithelium cDNA library [100]. The same group reported the identification of retroviral sequences in a murine model of PBC and the integration of the virus in cholangiocytes from patients with PBC [133]. There is no doubt that Mason's group has produced an extensive amount of data in support of a potential role of $\mathrm{HBRV}$ in the induction of PBC. However, an independent study by Selmi et al. [134] has failed to provide evidence in support of the role of betaretroviruses in the pathogenesis of $\mathrm{PBC}$. These authors found no evidence of infection by a PCR approach [134]. A third group also conducted a study in the same topic and 
found that the presence of MMTV (MMTV-LV) is not limited to PBC, but it can be found in livers of patients with a wide range of hepatic disorders and not in normal livers [135]. Thus, Johal et al. analyzed 210 liver biopsies and found evidence of MMTV in $25 \%$ of those. In fact, MMTV was present more often in non-PBC diseases livers $(27 \%)$ than in PBC livers $(12 \%)$, further indicating that if MMTV is probably involved in the induction of a liver disease which is likely to be happening in liver diseases other than PBC [135].

Of relevance to the practising physician, Mason's group has conducted pilot studies treating PBC patients with Combivir, an antiviral combination treatment consisted of zidovudine and lamivudine. Original data showing some biochemical and histological improvement of patients undergoing treatment [136] have been discarded by subsequent findings, demonstrating lack of efficacy and evidence of resistance to treatment with biochemical rebound [137].

\section{Unpopular infectious triggers of PBC}

\section{Helicobacter species}

Several studies have attempted to link Helicobacter pylori with the development of PBC [138-141]. Evidence of antihelicobacter antibody seropositivity has been found in serum samples from patients with PBC. Also, these antibodies are detectable in bile collected from PBC patients [138-141]. Further experiments have shown that animals immunized with helicobacter species can develop histological features resembling those seen in PBC [142]. However, there is no evidence of molecular mimicry between mitochondrial targets and the major helicobacter antigens [143].

\section{Typical and atypical Mycobacteria}

PBC is a granulomatous liver disease, and this has led the researchers to consider the possibility that M.tuberculosis and other mycobacterial infections may cause the disease [1, 144-146]. The presence of relatively low titres of AMA in patients with pulmonary tuberculosis and leprosy has added some support to the pathogenic role of mycobacteria in PBC [146, 147]. Others have considered atypical mycobacteria, such as M. gordonae, as important triggers of the disease, but the importance of the published data and their significance has been questioned [148]. Work conducted in Spain has suggested that patients with PBC contain antibodies reacting with the $65 \mathrm{kDa}$ heat shock protein of Mycobacterium gordonae [144, 145]. Subsequent studies reported the presence of antibodies that cross-recognise human PDC-E2 and mycobacterial hsp65 [149].

\section{Chlamydia pneumoniae}

Abdulkarim et al. [86] have obtained striking evidence of C. pneumoniae DNA in explanted liver tissues from $\mathrm{PBC}$, but not from patients with chronic hepatitis $\mathrm{C}$ or primary sclerosing cholangitis. A subsequent independent study did not confirm such findings [95]. PCR analysis did not reveal any evidence of C. pneumoniae DNA [95]. However, antichlamydial antibodies were found in the great majority of patients with PBC. Leung et al. [95] speculated that antichlamydial antibody seropostivity is due to the cross-recognition of mitochondrial autoantigens with the respective antigens from chlamydia.

\section{Epstein-Barr and human cytomegaloviruses}

Epstein-Barr virus (EBV) and human cytomegalovirus (HCMV) are two of the most frequently implicated viruses in the pathogenesis of autoimmune diseases [150, 151]. Their role in the pathogenesis of PBC remains obscure [152]. Experimental studies investigating the potential link of EBV with PBC are scarce. An early study investigating the activation status of B-cells of patients with PBC has found a reduced production of immunoglobulins by B-cells stimulated with EBV [153]. The same study has shown that EBV-stimulated cultures of lymphocytes from patients with PBC had diminished suppression of immunoglobulinsecreting cells [153]. A subsequent study has provided evidence of elevated levels of EBV-DNA in peripheral blood mononuclear cells isolated from patients with $\mathrm{PBC}$ compared to the levels noted in patients with AIH (61 vs. $19 \%$ ) [154]. Immunohistochemical analysis of liver tissues obtained from patients with $\mathrm{PBC}$ has also shown increased levels of EBV-DNA compared to those seen in patients with other liver diseases [154]. Increased levels of IgG antibodies against EBV early antigen have been found in patients with PBC compared to healthy controls. However, this finding was not specific for PBC as it was noted in patients with other diseases including patients with systemic lupus erythematosus, rheumatoid arthritis and multiple sclerosis [155].

Another study has shown inability of PDC-E2 mimics originating from EBV to act as a target of cross-reactive antibodies, suggesting that molecular mimicry between EBV and AMA targets is highly unlikely [66].

$\mathrm{HCMV}$ is a potent inducer of autoimmunity, but its role in PBC is far from clear. Elevated levels of IgM antibodies against CMV are detectable in patients with PBC compared to controls [155]. Again, such elevated levels are not 
specifically found in PBC but also in several other autoimmune diseases including patients with systemic lupus erythematosus, antiphospholipid syndrome, polymyositis, Sjögren's syndrome, systemic sclerosis, Churg-Strauss vasculitis, mixed cryoglobulinemia and other diseases [155].

However, IgG antibodies against CMV are not elevated in patients with $\mathrm{PBC}$ compared to healthy controls and several autoimmune diseases [155]. Also, human PDC-E2 responses do not cross-react with their CMV mimics, indicating the lack of a mechanism of molecular mimicry.

\section{Conclusion}

Epidemiological and experimental data have provided support to the notion that PBC may be an infectious disease caused by specific bacteria infecting predisposed individuals. Some microbes have been studied more than others. As for other autoimmune diseases, the most prevailing scenarios include those suggesting that molecular mimicry is the mechanism most likely involved in the infectioustriggered autoimmune phenomena seen in patients who develop PBC. Emerging data from animal models of the disease will shed light onto the involvement of infection(s) in the pathogenesis of PBC. Some work has been done on the role of E. coli and $N$. aromaticivorans, but there is little to suggest that these or other microbial agents are really needed for induction of the disease.

\section{Conflict of interest None.}

\section{References}

1. Kaplan MM, Gershwin ME (2005) Primary biliary cirrhosis. N Engl J Med 353:1261-1273

2. Lindor KD, Gershwin ME, Poupon R et al (2009) Primary biliary cirrhosis. Hepatology 50:291-308

3. Hohenester S, Oude-Elferink RP, Beuers U (2009) Primary biliary cirrhosis. Semin Immunopathol 31:283-307

4. Neuberger J (1997) Primary biliary cirrhosis. Lancet 350: 875-879

5. Kumagi T, Heathcote EJ (2008) Primary biliary cirrhosis. Orphanet J Rare Dis 3:1

6. Lazaridis KN, Juran BD, Boe GM et al (2007) Increased prevalence of antimitochondrial antibodies in first-degree relatives of patients with primary biliary cirrhosis. Hepatology 46:785-792

7. Bach N, Schaffner F (1994) Familial primary biliary cirrhosis. J Hepatol 20:698-701

8. Floreani A, Naccarato R, Chiaramonte M (1997) Prevalence of familial disease in primary biliary cirrhosis in Italy. J Hepatol 26:737-738

9. Tsuji K, Watanabe Y, Van De Water J (1999) Familial primary biliary cirrhosis in Hiroshima. J Autoimmun 13:171-178

10. Brind AM, Bray GP, Portmann BC et al (1995) Prevalence and pattern of familial disease in primary biliary cirrhosis. Gut 36:615-617
11. Jones DE, Watt FE, Metcalf JV et al (1999) Familial primary biliary cirrhosis reassessed: a geographically-based population study. J Hepatol 30:402-407

12. Poupon R (2010) Primary biliary cirrhosis: a 2010 update. J Hepatol 52:745-758

13. European Association for the Study of the Liver (2009) EASL Clinical Practice Guidelines: management of cholestatic liver diseases. J Hepatol 51:237-267

14. Prince MI, Chetwynd A, Craig WL et al (2004) Asymptomatic primary biliary cirrhosis: clinical features, prognosis, and symptom progression in a large population based cohort. Gut 53:865-870

15. Bogdanos DP, Komorowski L (2011) Disease-specific autoantibodies in primary biliary cirrhosis. Clin Chim Acta 412: 502-512

16. Bogdanos DP, Invernizzi P, Mackay IR et al (2008) Autoimmune liver serology: current diagnostic and clinical challenges. World J Gastroenterol 14:3374-3387

17. Bogdanos DP, Baum H, Vergani D (2003) Antimitochondrial and other autoantibodies. Clin Liver Dis 7:759-777, vi

18. Courvalin JC, Worman HJ (1997) Nuclear envelope protein autoantibodies in primary biliary cirrhosis. Semin Liver Dis 17:79-90

19. Szostecki C, Guldner HH, Will H (1997) Autoantibodies against "nuclear dots" in primary biliary cirrhosis. Semin Liver Dis 17:71-78

20. Baum H, Berg PA (1981) The complex nature of mitochondrial antibodies and their relation to primary biliary cirrhosis. Semin Liver Dis 1:309-321

21. Bogdanos DP, Mieli-Vergani G, Vergani D (2009) Autoantibodies and their antigens in autoimmune hepatitis. Semin Liver Dis 29:241-253

22. Mackay IR (1958) Primary biliary cirrhosis showing a high titer of autoantibody; report of a case. N Engl J Med 258:185-188

23. Walker JG, Doniach D, Roitt IM et al (1965) Serological tests in diagnosis of primary biliary cirrhosis. Lancet 1:827-831

24. Leung PS, Rossaro L, Davis PA et al (2007) Antimitochondrial antibodies in acute liver failure: implications for primary biliary cirrhosis. Hepatology 46:1436-1442

25. Metcalf JV, Mitchison HC, Palmer JM et al (1996) Natural history of early primary biliary cirrhosis. Lancet 348:1399-1402

26. Mitchison HC, Bassendine MF, Hendrick A et al (1986) Positive antimitochondrial antibody but normal alkaline phosphatase: is this primary biliary cirrhosis? Hepatology 6:1279-1284

27. Berg PA, Doniach D, Roitt IM (1967) Mitochondrial antibodies in primary biliary cirrhosis. I. Localization of the antigen to mitochondrial membranes. J Exp Med 126:277-290

28. Fussey SP, Lindsay JG, Fuller C et al (1991) Autoantibodies in primary biliary cirrhosis: analysis of reactivity against eukaryotic and prokaryotic 2-oxo acid dehydrogenase complexes. Hepatology 13:467-474

29. Gershwin ME, Mackay IR, Sturgess A et al (1987) Identification and specificity of a cDNA encoding the $70 \mathrm{kd}$ mitochondrial antigen recognized in primary biliary cirrhosis. J Immunol 138:3525-3531

30. Van de Water J, Cooper A, Surh CD et al (1989) Detection of autoantibodies to recombinant mitochondrial proteins in patients with primary biliary cirrhosis. N Engl J Med 320:1377-1380

31. Van de Water J, Fregeau D, Davis P et al (1988) Autoantibodies of primary biliary cirrhosis recognize dihydrolipoamide acetyltransferase and inhibit enzyme function. J Immunol 141: 2321-2324

32. Van de Water J, Gershwin ME, Leung P et al (1988) The autoepitope of the 74-kD mitochondrial autoantigen of primary biliary cirrhosis corresponds to the functional site of dihydrolipoamide acetyltransferase. J Exp Med 167:1791-1799 
33. Dubel L, Tanaka A, Leung PS et al (1999) Autoepitope mapping and reactivity of autoantibodies to the dihydrolipoamide dehydrogenase-binding protein (E3BP) and the glycine cleavage proteins in primary biliary cirrhosis. Hepatology 29:10131018

34. Mackay IR, Whittingham S, Fida S et al (2000) The peculiar autoimmunity of primary biliary cirrhosis. Immunol Rev 174: 226-237

35. Leung PS, Coppel RL, Ansari A et al (1997) Antimitochondrial antibodies in primary biliary cirrhosis. Semin Liver Dis 17:61-69

36. Palmer JM, Jones DE, Quinn J et al (1999) Characterization of the autoantibody responses to recombinant E3 binding protein (protein $\mathrm{X}$ ) of pyruvate dehydrogenase in primary biliary cirrhosis. Hepatology 30:21-26

37. Yeaman SJ, Fussey SP, Danner DJ et al (1988) Primary biliary cirrhosis: identification of two major M2 mitochondrial autoantigens. Lancet 1:1067-1070

38. Yeaman SJ, Kirby JA, Jones DE (2000) Autoreactive responses to pyruvate dehydrogenase complex in the pathogenesis of primary biliary cirrhosis. Immunol Rev 174:238-249

39. Van Norstrand MD, Malinchoc M, Lindor KD et al (1997) Quantitative measurement of autoantibodies to recombinant mitochondrial antigens in patients with primary biliary cirrhosis: relationship of levels of autoantibodies to disease progression. Hepatology 25:6-11

40. Rigopoulou EI, Bogdanos DP, Liaskos C et al (2007) Antimitochondrial antibody immunofluorescent titres correlate with the number and intensity of immunoblot-detected mitochondrial bands in patients with primary biliary cirrhosis. Clin Chim Acta 380:118-121

41. Rigopoulou EI, Davies ET, Bogdanos DP et al (2007) Antimitochondrial antibodies of immunoglobulin G3 subclass are associated with a more severe disease course in primary biliary cirrhosis. Liver Int 27:1226-1231

42. Dahnrich C, Pares A, Caballeria L et al (2009) New ELISA for detecting primary biliary cirrhosis-specific antimitochondrial antibodies. Clin Chem 55:978-985

43. Liaskos C, Bogdanos DP, Rigopoulou EI et al (2007) Development of antimitochondrial antibodies in patients with autoimmune hepatitis: art of facts or an artifact? J Gastroenterol Hepatol 22:454-455

44. Liu H, Norman GL, Shums Z et al (2010) PBC screen: an IgG/ IgA dual isotype ELISA detecting multiple mitochondrial and nuclear autoantibodies specific for primary biliary cirrhosis. J Autoimmun 35:436-442

45. Moteki S, Leung PS, Coppel RL et al (1996) Use of a designer triple expression hybrid clone for three different lipoyl domain for the detection of antimitochondrial autoantibodies. Hepatology 24:97-103

46. Bernal W, Meda F, Ma Y et al (2008) Disease-specific autoantibodies in patients with acute liver failure: the King's College London Experience. Hepatology 47:1096-1097

47. Gabeta S, Norman GL, Liaskos C et al (2007) Diagnostic relevance and clinical significance of the new enhanced performance M2 (MIT3) ELISA for the detection of IgA and IgG antimitochondrial antibodies in primary biliary cirrhosis. J Clin Immunol 27:378-387

48. Miyakawa H, Tanaka A, Kikuchi K et al (2001) Detection of antimitochondrial autoantibodies in immunofluorescent AMAnegative patients with primary biliary cirrhosis using recombinant autoantigens. Hepatology 34:243-248

49. Muratori L, Muratori P, Granito A et al (2005) The Western immunoblotting pattern of anti-mitochondrial antibodies is independent of the clinical expression of primary biliary cirrhosis. Dig Liver Dis 37:108-112
50. Mytilinaiou MG, Bogdanos DP (2009) Primary biliary cirrhosisspecific autoantibodies in patients with systemic sclerosis. Dig Liver Dis 41:916 author reply 916-917

51. Oertelt S, Rieger R, Selmi C et al (2007) A sensitive bead assay for antimitochondrial antibodies: chipping away at AMA-negative primary biliary cirrhosis. Hepatology 45:659-665

52. Bogdanos DP, Baum H, Okamoto M et al (2005) Primary biliary cirrhosis is characterized by IgG3 antibodies cross-reactive with the major mitochondrial autoepitope and its Lactobacillus mimic. Hepatology 42:458-465

53. Muratori P, Muratori L, Ferrari R et al (2003) Characterization and clinical impact of antinuclear antibodies in primary biliary cirrhosis. Am J Gastroenterol 98:431-437

54. Janka C, Selmi C, Gershwin ME et al (2005) Small ubiquitinrelated modifiers: a novel and independent class of autoantigens in primary biliary cirrhosis. Hepatology 41:609-616

55. Jones DE (2007) Pathogenesis of primary biliary cirrhosis. Gut 56:1615-1624

56. Jones DE, Donaldson PT (2003) Genetic factors in the pathogenesis of primary biliary cirrhosis. Clin Liver Dis 7:841-864

57. Invernizzi P, Selmi C, Ranftler C et al (2005) Antinuclear antibodies in primary biliary cirrhosis. Semin Liver Dis 25: 298-310

58. Wesierska-Gadek J, Hohenuer H, Hitchman E et al (1996) Autoantibodies against nucleoporin p62 constitute a novel marker of primary biliary cirrhosis. Gastroenterology 110 : 840-847

59. Vergani D, Bogdanos DP (2003) Positive markers in AMAnegative PBC. Am J Gastroenterol 98:241-243

60. Bogdanos DP, Liaskos C, Pares A et al (2007) Anti-gp210 antibody mirrors disease severity in primary biliary cirrhosis. Hepatology 45:1583 author reply 1583-1584

61. Wesierska-Gadek J, Penner E, Battezzati PM et al (2006) Correlation of initial autoantibody profile and clinical outcome in primary biliary cirrhosis. Hepatology 43:1135-1144

62. Nakamura M, Kondo H, Mori T et al (2007) Anti-gp210 and anti-centromere antibodies are different risk factors for the progression of primary biliary cirrhosis. Hepatology 45:118-127

63. Itoh S, Ichida T, Yoshida T et al (1998) Autoantibodies against a $210 \mathrm{kDa}$ glycoprotein of the nuclear pore complex as a prognostic marker in patients with primary biliary cirrhosis. J Gastroenterol Hepatol 13:257-265

64. Invernizzi P, Podda M, Battezzati PM et al (2001) Autoantibodies against nuclear pore complexes are associated with more active and severe liver disease in primary biliary cirrhosis. J Hepatol 34:366-372

65. Bogdanos DP, Pares A, Rodes J et al (2004) Primary biliary cirrhosis specific antinuclear antibodies in patients from Spain. Am J Gastroenterol 99:763-764 author reply 765

66. Bogdanos DP, Baum H, Grasso A et al (2004) Microbial mimics are major targets of crossreactivity with human pyruvate dehydrogenase in primary biliary cirrhosis. J Hepatol 40:31-39

67. Yang WH, Yu JH, Nakajima A et al (2004) Do antinuclear antibodies in primary biliary cirrhosis patients identify increased risk for liver failure? Clin Gastroenterol Hepatol 2:1116-1122

68. Lassoued K, Brenard R, Degos F et al (1990) Antinuclear antibodies directed to a 200-kilodalton polypeptide of the nuclear envelope in primary biliary cirrhosis. A clinical and immunological study of a series of 150 patients with primary biliary cirrhosis. Gastroenterology 99:181-186

69. Bogdanos DP, Mieli-Vergani G, Vergani D (2000) Virus, liver and autoimmunity. Dig Liver Dis 32:440-446

70. Bogdanos DP, Vergani D (2006) Origin of cross-reactive autoimmunity in primary biliary cirrhosis. Liver Int 26:633-635

71. Neuberger J, Thomson R (1999) PBC and AMA-what is the connection? Hepatology 29:271-276 
72. Smyk D, Cholongitas E, Kriese S et al (2011) Primary biliary cirrhosis: family stories. Autoimmune Dis 2011:189585

73. Gershwin ME, Mackay IR (2008) The causes of primary biliary cirrhosis: convenient and inconvenient truths. Hepatology 47:737-745

74. Bogdanos DP, Choudhuri K, Vergani D (2001) Molecular mimicry and autoimmune liver disease: virtuous intentions, malign consequences. Liver 21:225-232

75. Lleo A, Selmi C, Invernizzi P et al (2009) Apotopes and the biliary specificity of primary biliary cirrhosis. Hepatology 49:871-879

76. Gershwin ME, Mackay IR (1991) Primary biliary cirrhosis: paradigm or paradox for autoimmunity. Gastroenterology 100:822-833

77. Smyk DS, Bogdanos DP, Kriese S et al (2012) Urinary tract infection as a risk factor for autoimmune liver disease: from bench to bedside. Clin Res Hepatol Gastroenterol 36:110-121

78. Smyk DS, Rigopoulou EI, Lleo A et al (2011) Immunopathogenesis of primary biliary cirrhosis: an old wives' tale. Immun Ageing 8:12

79. Bogdanos D, Pusl T, Rust C et al (2008) Primary biliary cirrhosis following Lactobacillus vaccination for recurrent vaginitis. J Hepatol 49:466-473

80. Bogdanos DP, Baum H, Butler P et al (2003) Association between the primary biliary cirrhosis specific anti-sp100 antibodies and recurrent urinary tract infection. Dig Liver Dis 35:801-805

81. Bogdanos DP, Baum H, Sharma UC et al (2002) Antibodies against homologous microbial caseinolytic proteases $\mathrm{P}$ characterise primary biliary cirrhosis. J Hepatol 36:14-21

82. Bogdanos DP, Baum H, Vergani D et al (2010) The role of E. coli infection in the pathogenesis of primary biliary cirrhosis. Dis Markers 29:301-311

83. Koutsoumpas A, Mytilinaiou M, Polymeros D et al (2009) AntiHelicobacter pylori antibody responses specific for VacA do not trigger primary biliary cirrhosis-specific antimitochondrial antibodies. Eur J Gastroenterol Hepatol 21:1220

84. Shimoda S, Nakamura M, Shigematsu H et al (2000) Mimicry peptides of human PDC-E2 163-176 peptide, the immunodominant T-cell epitope of primary biliary cirrhosis. Hepatology 31:1212-1216

85. Shimoda S, Van de Water J, Ansari A et al (1998) Identification and precursor frequency analysis of a common $\mathrm{T}$ cell epitope motif in mitochondrial autoantigens in primary biliary cirrhosis. J Clin Invest 102:1831-1840

86. Abdulkarim AS, Petrovic LM, Kim WR et al (2004) Primary biliary cirrhosis: an infectious disease caused by Chlamydia pneumoniae? J Hepatol 40:380-384

87. Burroughs AK, Butler P, Sternberg MJ et al (1992) Molecular mimicry in liver disease. Nature 358:377-378

88. Burroughs AK, Rosenstein IJ, Epstein O et al (1984) Bacteriuria and primary biliary cirrhosis. Gut 25:133-137

89. Butler P, Hamilton-Miller J, Baum H et al (1995) Detection of M2 antibodies in patients with recurrent urinary tract infection using an ELISA and purified $\mathrm{PBC}$ specific antigens. Evidence for a molecular mimicry mechanism in the pathogenesis of primary biliary cirrhosis? Biochem Mol Biol Int 35:473-485

90. Butler P, Hamilton-Miller JM, McIntyre N et al (1995) Natural history of bacteriuria in women with primary biliary cirrhosis and the effect of antimicrobial therapy in symptomatic and asymptomatic groups. Gut 36:931-934

91. Butler P, Valle F, Hamilton-Miller JM et al (1993) M2 mitochondrial antibodies and urinary rough mutant bacteria in patients with primary biliary cirrhosis and in patients with recurrent bacteriuria. J Hepatol 17:408-414
92. Donaldson PT (2004) Genetics of liver disease: immunogenetics and disease pathogenesis. Gut 53:599-608

93. Floreani A, Bassendine MF, Mitchison H et al (1989) No specific association between primary biliary cirrhosis and bacteriuria? J Hepatol 8:201-207

94. Invernizzi P, Miozzo M, Battezzati PM et al (2004) Frequency of monosomy $\mathrm{X}$ in women with primary biliary cirrhosis. Lancet 363:533-535

95. Leung PS, Park O, Matsumura S et al (2003) Is there a relation between Chlamydia infection and primary biliary cirrhosis? Clin Dev Immunol 10:227-233

96. Mason A, Xu L, Shen Z et al (2004) Patients with primary biliary cirrhosis make anti-viral and anti-mitochondrial antibodies to mouse mammary tumor virus. Gastroenterology 127:1863-1864 author reply 1864-1865

97. McNally RJ, Ducker S, James OF (2009) Are transient environmental agents involved in the cause of primary biliary cirrhosis? Evidence from space-time clustering analysis. Hepatology 50:1169-1174

98. Selmi C, Balkwill DL, Invernizzi P et al (2003) Patients with primary biliary cirrhosis react against a ubiquitous xenobioticmetabolizing bacterium. Hepatology 38:1250-1257

99. Smyk D, Mytilinaiou MG, Rigopoulou EI et al (2010) PBC triggers in water reservoirs, coal mining areas and waste disposal sites: from Newcastle to New York. Dis Markers 29:337-344

100. Xu L, Sakalian M, Shen $\mathrm{Z}$ et al (2004) Cloning the human betaretrovirus proviral genome from patients with primary biliary cirrhosis. Hepatology 39:151-156

101. Xu L, Shen Z, Guo L et al (2003) Does a betaretrovirus infection trigger primary biliary cirrhosis? Proc Natl Acad Sci USA 100:8454-8459

102. Smyk D, Rigopoulou EI, Baum H et al (2012) Autoimmunity and environment: am I at risk? Clin Rev Allergy Immunol 42:199-212

103. Smyk D, Mytilinaiou MG, Milkiewicz P et al (2012) Towards systemic sclerosis and away from primary biliary cirrhosis: the case of PTPN22. Autommunity Highlights 3:1-9

104. Smyk D, Rigopoulou EI, Bizzaro N et al (2012) Hair dyes as a risk for autoimmunity: from systemic lupus erythematosus to primary biliary cirrhosis. Autoimmunity Highlights. doi:10. 1007/s13317-011-0027-7

105. Smyk DS, Rigopoulou EI, Muratori L et al (2012) Smoking as a risk factor for autoimmune liver disease: what we can learn from primary biliary cirrhosis. Ann Hepatol 11:7-14

106. Smyk DS, Rigopoulou EI, Pares A et al (2012) Sex differences associated with primary biliary cirrhosis. Clin Dev Immunol 2012:610504

107. Smyk DS, Rigopoulou EI, Pares A et al (2012) Familial primary biliary cirrhosis: like mother, like daughter? Acta Gastroenterol Belg 75:203-209

108. Svyryd Y, Hernandez-Molina G, Vargas F et al (2012) X chromosome monosomy in primary and overlapping autoimmune diseases. Autoimmun Rev 11:301-304

109. Mayo I, Arizti P, Pares A et al (2000) Antibodies against the $\mathrm{COOH}$-terminal region of $E$. coli $\mathrm{ClpP}$ protease in patients with primary biliary cirrhosis. J Hepatol 33:528-536

110. Bogdanos DP, Vergani D (2009) Bacteria and primary biliary cirrhosis. Clin Rev Allergy Immunol 36:30-39

111. Morreale M, Tsirigotis M, Hughes MD et al (1989) Significant bacteriuria has prognostic significance in primary biliary cirrhosis. J Hepatol 9:149-158

112. Gershwin ME, Selmi C, Worman HJ et al (2005) Risk factors and comorbidities in primary biliary cirrhosis: a controlled interview-based study of 1032 patients. Hepatology 42:11941202 
113. Corpechot C, Chretien Y, Chazouilleres O et al (2010) Demographic, lifestyle, medical and familial factors associated with primary biliary cirrhosis. J Hepatol 53:162-169

114. Tanaka A, Prindiville TP, Gish R et al (1999) Are infectious agents involved in primary biliary cirrhosis? A PCR approach. J Hepatol 31:664-671

115. Oldstone MB (1987) Molecular mimicry and autoimmune disease. Cell 50:819-820

116. Vergani D, Longhi MS, Bogdanos DP et al (2009) Autoimmune hepatitis. Semin Immunopathol 31:421-435

117. Alvaro D, Invernizzi P, Onori P et al (2004) Estrogen receptors in cholangiocytes and the progression of primary biliary cirrhosis. J Hepatol 41:905-912

118. Mattner J, Savage PB, Leung P et al (2008) Liver autoimmunity triggered by microbial activation of natural killer $\mathrm{T}$ cells. Cell Host Microbe 3:304-315

119. Padgett KA, Selmi C, Kenny TP et al (2005) Phylogenetic and immunological definition of four lipoylated proteins from Novosphingobium aromaticivorans, implications for primary biliary cirrhosis. J Autoimmun 24:209-219

120. Olafsson S, Gudjonsson H, Selmi C et al (2004) Antimitochondrial antibodies and reactivity to $N$. aromaticivorans proteins in Icelandic patients with primary biliary cirrhosis and their relatives. Am J Gastroenterol 99:2143-2146

121. Baum H (1989) Nature of the mitochondrial antigens of primary biliary cirrhosis and their possible relationships to the etiology of the disease. Semin Liver Dis 9:117-123

122. Baum H (1995) Mitochondrial antigens, molecular mimicry and autoimmune disease. Biochim Biophys Acta 1271:111-121

123. Fussey SP, Ali ST, Guest JR et al (1990) Reactivity of primary biliary cirrhosis sera with Escherichia coli dihydrolipoamide acetyltransferase (E2p): characterization of the main immunogenic region. Proc Natl Acad Sci USA 87:3987-3991

124. Fussey SP, Bassendine MF, James OF et al (1989) Characterisation of the reactivity of autoantibodies in primary biliary cirrhosis. FEBS Lett 246:49-53

125. Van de Water J, Ishibashi H, Coppel RL et al (2001) Molecular mimicry and primary biliary cirrhosis: premises not promises. Hepatology 33:771-775

126. Shigematsu H, Shimoda S, Nakamura M et al (2000) Fine specificity of $T$ cells reactive to human PDC-E2 163-176 peptide, the immunodominant autoantigen in primary biliary cirrhosis: implications for molecular mimicry and crossrecognition among mitochondrial autoantigens. Hepatology 32:901-909

127. Parikh-Patel A, Gold EB, Worman H et al (2001) Risk factors for primary biliary cirrhosis in a cohort of patients from the united states. Hepatology 33:16-21

128. O'Donohue J, Workman MR, Rolando N et al (1997) Urinary tract infections in primary biliary cirrhosis and other chronic liver diseases. Eur J Clin Microbiol Infect Dis 16:743-746

129. Varyani FK, West J, Card TR (2011) An increased risk of urinary tract infection precedes development of primary biliary cirrhosis. BMC Gastroenterol 11:95

130. Selmi C (2011) The evidence does not support a viral etiology for primary biliary cirrhosis. J Hepatol 54:1315-1316

131. Mason AL (2011) The evidence supports a viral aetiology for primary biliary cirrhosis. J Hepatol 54:1312-1314

132. Mason AL, Xu L, Guo L et al (1998) Detection of retroviral antibodies in primary biliary cirrhosis and other idiopathic biliary disorders. Lancet 351:1620-1624

133. Zhang G, Chen M, Graham D et al (2011) Mouse mammary tumor virus in anti-mitochondrial antibody producing mouse models. J Hepatol 55:876-884

134. Selmi C, Ross SR, Ansari AA et al (2004) Lack of immunological or molecular evidence for a role of mouse mammary tumor retrovirus in primary biliary cirrhosis. Gastroenterology 127:493-501

135. Johal H, Scott GM, Jones R et al (2009) Mouse mammary tumour virus-like virus (MMTV-LV) is present within the liver in a wide range of hepatic disorders and unrelated to nuclear p53 expression or hepatocarcinogenesis. J Hepatol 50:548-554

136. Mason AL, Farr GH, Xu L et al (2004) Pilot studies of single and combination antiretroviral therapy in patients with primary biliary cirrhosis. Am J Gastroenterol 99:2348-2355

137. Mason AL, Lindor KD, Bacon BR et al (2008) Clinical Trial: Randomized controlled trial of zidovudine and lamivudine for patients with primary biliary cirrhosis stabilized on ursodiol. Aliment Pharmacol Ther 28:886-894

138. Nilsson HO, Castedal M, Olsson R et al (1999) Detection of Helicobacter in the liver of patients with chronic cholestatic liver diseases. J Physiol Pharmacol 50:875-882

139. Nilsson HO, Taneera J, Castedal M et al (2000) Identification of Helicobacter pylori and other Helicobacter species by PCR, hybridization, and partial DNA sequencing in human liver samples from patients with primary sclerosing cholangitis or primary biliary cirrhosis. J Clin Microbiol 38:1072-1076

140. Nilsson I, Lindgren S, Eriksson S et al (2000) Serum antibodies to Helicobacter hepaticus and Helicobacter pylori in patients with chronic liver disease. Gut 46:410-414

141. Nilsson I, Kornilovs'ka I, Lindgren S et al (2003) Increased prevalence of seropositivity for non-gastric Helicobacter species in patients with autoimmune liver disease. J Med Microbiol 52:949-953

142. Fallone CA, Tran S, Semret M et al (2003) Helicobacter DNA in bile: correlation with hepato-biliary diseases. Aliment Pharmacol Ther 17:453-458

143. Bogdanos DP, Baum H, Gunsar F et al (2004) Extensive homology between the major immunodominant mitochondrial antigen in primary biliary cirrhosis and Helicobacter pylori does not lead to immunological cross-reactivity. Scand J Gastroenterol 39:981-987

144. Vilagut L, Pares A, Vinas O et al (1997) Antibodies to mycobacterial $65-\mathrm{kD}$ heat shock protein cross-react with the main mitochondrial antigens in patients with primary biliary cirrhosis. Eur J Clin Invest 27:667-672

145. Vilagut L, Vila J, Vinas O et al (1994) Cross-reactivity of antiMycobacterium gordonae antibodies with the major mitochondrial autoantigens in primary biliary cirrhosis. J Hepatol 21:673-677

146. Gilburd B, Ziporen L, Zharhary D et al (1994) Antimitochondrial (pyruvate dehydrogenase) antibodies in leprosy. J Clin Immunol 14:14-19

147. Klein R, Wiebel M, Engelhart S et al (1993) Sera from patients with tuberculosis recognize the M2a-epitope (E2-subunit of pyruvate dehydrogenase) specific for primary biliary cirrhosis. Clin Exp Immunol 92:308-316

148. O’Donohue J, McFarlane B, Bomford A et al (1994) Antibodies to atypical mycobacteria in primary biliary cirrhosis. J Hepatol 21:887-889

149. Bogdanos DP, Pares A, Baum H et al (2004) Disease-specific cross-reactivity between mimicking peptides of heat shock protein of Mycobacterium gordonae and dominant epitope of E2 subunit of pyruvate dehydrogenase is common in Spanish but not British patients with primary biliary cirrhosis. J Autoimmun 22:353-362

150. Toussirot E, Roudier J (2008) Epstein-Barr virus in autoimmune diseases. Best Pract Res Clin Rheumatol 22:883-896

151. Niller HH, Wolf H, Minarovits J (2008) Regulation and dysregulation of Epstein-Barr virus latency: implications for the development of autoimmune diseases. Autoimmunity 41: 298-328 
152. Rigopoulou EI, Smyk DS, Matthews CE et al (2012) Epsteinbarr virus as a trigger of autoimmune liver diseases. Adv Virol 2012:987471

153. James SP, Jones EA, Hoofnagle JH et al (1985) Circulating activated B cells in primary biliary cirrhosis. J Clin Immunol 5:254-260

154. Morshed SA, Nishioka M, Saito I et al (1992) Increased expression of Epstein-Barr virus in primary biliary cirrhosis patients. Gastroenterol Jpn 27:751-758
155. Barzilai O, Sherer Y, Ram M et al (2007) Epstein-Barr virus and cytomegalovirus in autoimmune diseases: are they truly notorious? A preliminary report. Ann N Y Acad Sci 1108:567-577

156. Palermo JJ (2008) Recurrent urinary tract infection in mice results in immune-mediated cholangiopathy similar to human primary biliary cirrhosis. Gastroenterology 134:A837 